\title{
ЖИЛЬНЫЕ ПОРОДЫ МОНЧЕГОРСКОГО КОМПЛЕКСА КАК ВАЖНЫЙ ЭЛЕМЕНТ ЕГО ПРОМЫШЛЕННОГО ПОТЕНЦИАЛА
}

\section{Припачкин П.В., Мирошникова Я.А.}

Геологический институт КНЦ РАН, Anamumbl, paul@geoksc.apatity.ru

Дайковые и жильные образования, широко развитые в различных магматических комплексах, являются важными индикаторами различных обстановок формирования интрузий и, во многих случаях, их рудной минерализации. Очень часто различные дайки и жилы (особенно пегматоидные) бывают приурочены к так называемым «краевым сериям» интрузивов, характеризующихся также повсеместным развитием различных брекчий и несущих «контактовое» сульфидное и ЭПГ оруденение. Большой промышленный интерес вызывают также «рудные жилы», сложенные сплошными сульфидами. В связи с изложенным, далее мы остановимся на рассмотрении подобных образований (рудных и пегматоидных жил, зон брекчирования и контактного оруденения) в пределах палеопротерозойского расслоенного Мончегорского комплекса (Мончеплутон+Мончетундровская интрузия).

Необходимо отметить, что само внедрение мафит-ультрамафитовых пород Мончеплутона обусловило интенсивное брекчирование, рассланцевание и метаморфическое преобразование вмещающих диорито-гнейсов, в которых на более поздних стадиях возникли плагиоклаз-кварцевые и гранитные жилы, а также дайки метагаббродолеритов, залегающие несогласно с толщей метадиоритогнейсов. Данные взаимоотношения пород можно наблюдать в прекрасно отпрепарированном участке так называемого «диоритового окна».

Жильные и дайковые образования достаточно широко развиты и в интрузивных комплексах Мончегорского рудного района. Так, интрузия Главного хребта сечется мелкими интрузиями клинопироксенит-верлитового комплекса, а также жил габбро-пегматитов и поздних анортозитов, даек гарризитов и более поздних долеритов, ферродолеритов и ферропикритов, различной мощности и протяженности [6].

Интрузивные породы Мончеплутона пересекаются жилами пегматитов основного и среднего состава (часто называемыми габбро-пегматитами) и дайками диоритов, долеритов и лампрофиров, а также жильными телами богатых сульфидных руд, залегающими в пределах массивов НКТ и горы Сопча. На горе Ниттис сульфидные жилы часто переходят на глубине в рудно-силикатные пегматиты отвечающие по составу норитам, габброноритам и диоритам [6].

В пределах «Критическго горизонта» массива Нюд выделяются жильные и гнездообразные тела пегматитов и рудных пегматитов основного состава, приуроченные как к контактам различных пород, так и выполняющие системы субвертикальных трещин. По мнению В.Ф. Смолькина, ранее горизонт представлял собою кровлю первичной камеры. При внедрении новых порций расплава, материал бывшей кровли частично подвергся плавлению с образованием системы жил основного состава [6].

Следует подчеркнуть, что жильным породам Мончегорского комплекса не придавалось большого значения до тех пор, пока не были открыты уникальные богатые сульфидные жилы массивов НКТ и Сопча, полностью отработанные в течение двух десятилетий. Подробная характеристика строения и состава жил массива НКТ дана В.А. Маслениковым и П.В. Лялиным [2] Сульфидные жилы вытянуты вдоль длинной оси массива и имеют меридиональное или северо-восточное простирание. Залегая практически вертикально, они не выходят за пределы массива, выклиниваясь по простиранию и падению. Месторождение насчитывало 51 рудную жилу. Длина жил 100-1400 м, протяженность на глубину 30-440 м, мощность от нескольких сантиметров до 2-3 м, обычно - 20-60 см. Жилы сложены сплошными рудами, состоящими преимущественно из пирротина, пентландита, халькопирита и магнетита.

В.А. Маслеников и П.В. Лялин [2] отмечают, что в направлении на юг по простиранию сульфидные жилы переходят в жилы габбро-пегматитов, преобладающими минералами которых являются плагиоклаз и амфиболизированные пироксены. В северной и южной частях НКТ сульфидные жилы по простиранию переходят в магнетитовые. В.А. Маслеников и П.В. Лялин пришли к выводу, 
что в участках, близких к корням интрузии НКТ ультрабазиты пересекаются жилами норитов и габброноритов, которые севернее сменяются жильными породами типа габбро-пегматитов, далее типичными крупнозернистыми пегматитами, которые по простиранию переходят в собственно сульфидные жилы [2].

Жильные сульфидные тела в массиве Сопча были обнаружены при бурении глубоких скважин. Они состоят из сульфидов и магнетита, а также из карбонатов, хлорита, актинолита. Жильное поле горы Сопча представлено крутопадающими на юго-восток $\left(80-90^{\circ}\right)$ жилами с простиранием 20-30 ${ }^{\circ}$ в северо-восточной и 50-60 ${ }^{\circ}$ в юго-западной части. В массиве Сопча установлено 13 жил, связанных с зонами повышенной трещиноватости и бластомилонитизации. Объем жильного оруденения в массиве Сопча значительно меньше, чем в массиве НКТ. Мощность жил сравнительно невелика, раздувы и гнезда основных пегматитов практически отсутствуют [6].

Рудные поля НКТ и Сопчи формируют веерообразно расходящийся от сочленения Мончеплутона с Мончетундровской интрузией пучок жил север-северо-восточного простирания с азимутами от $0^{\circ}$ до $20^{\circ}$ в массиве НКТ и от $20^{\circ}$ до $50^{\circ}$ в массиве Сопча. По мнению большинства исследователей, крутопадающие жилы сформировались на заключительных стадиях развития Мончегорского комплекса путем заполнения тектонических трещин, образовавшихся после затвердевания интрузии [6].

Жильная сульфидная и ЭПГ минерализация в пределах НКТ была детально изучена и в ходе относительно недавних работ в пределах участка Западный Ниттис. Помимо известной ранее магматической вкрапленной малосульфидной минерализации «донной залежи», здесь работами ОАО «Центрально-Кольская экспедиция» в 2012 г. впервые установлена эпигенетическая минерализация, включающая в себя сульфидные жилы и прожилковые зоны, вкрапленную минерализацию и богатые сульфидами шлиры, значительная часть из которых содержит высокие концентрации ЭПГ $( \pm \mathrm{Au})[5]$.

Эта минерализация образует две системы сульфидных жил. Первая (субвертикальная относительно расслоенности) выполнена сульфидными жилами толщиной до 1-2 см, окруженными ореолами вторичных изменений пород. Жилы имеют невыдержанную мощность, неровные границы, иногда переходя в сульфидные шлиры (видимая мощность до 5 см), сульфидный материал жил обогащен ЭПГ (до 1-10 кг/т). Вторая формирует многочисленные тонкие жилы и прожилки с резкими границами, без существенных вторичных изменений. Минеральный состав жил представлен халькопиритом, второстепенные минералы - миллеритом, пентландитом и борнитом. Помимо этого, встречена богатая эпигенетическая платинометальная минерализация в дайке долеритов, секущей сульфидные жилы. В жилах и дайке долеритов выявлено более 20 минералов ЭПГ и Аu [5].

Что касается зоны сочленения Мончеплутона и Мончетундровской интрузии, то ее строение было детально изучено В.С. Докучаевой в пределах так называемого «юго-западного приконтактового участка Мончегорского плутона», характеризующего придонную часть массива НКТ. Обобщенный разрез охарактеризован на основе разрезов по линиям бурения глубоких скважин. В зоне наблюдается переслаивание пироксенитов и перидотитов, аналогичных породам Мончеплутона; габбро, аналогичных породам Главного хребта, а также габбро- и диорит-пегматитов. Жильные габбро-пегматиты имеют мощности от нескольких сантиметров до 1 м. В пироксенитах встречаются жилки пегматоидных пород основного, реже среднего и кислого состава, представленные лейкократовыми кварцевыми габбро, диоритами и гранофирами. В большей части интервала пироксенитов жильные породы встречаются в виде единичных жилок, но на отдельных глубинах они образуют густую сеть. Мощность жилок колеблется от десятых долей сантиметра до 30-35 см. Там, где они образуют густую сеть, остроугольные обломки пироксенита сцементированы жильной породой, т.е. породу в целом можно назвать «эруптивной брекчией». Нередко с жилами связана вкрапленность сульфидов и других рудных минералов. В некоторых габбро-пегматитах сульфидные вкрапленники достигают размера 1-2 см в поперечнике и окружены ореолом тонкой рассеянной вкрапленности. Главными минералами являются магнетит, титаномагнетит, халькопирит, пирротин, меньшую роль играют пентландит, борнит, пирит, иногда встречаются миллерит и минералы платиновой группы [4]. 

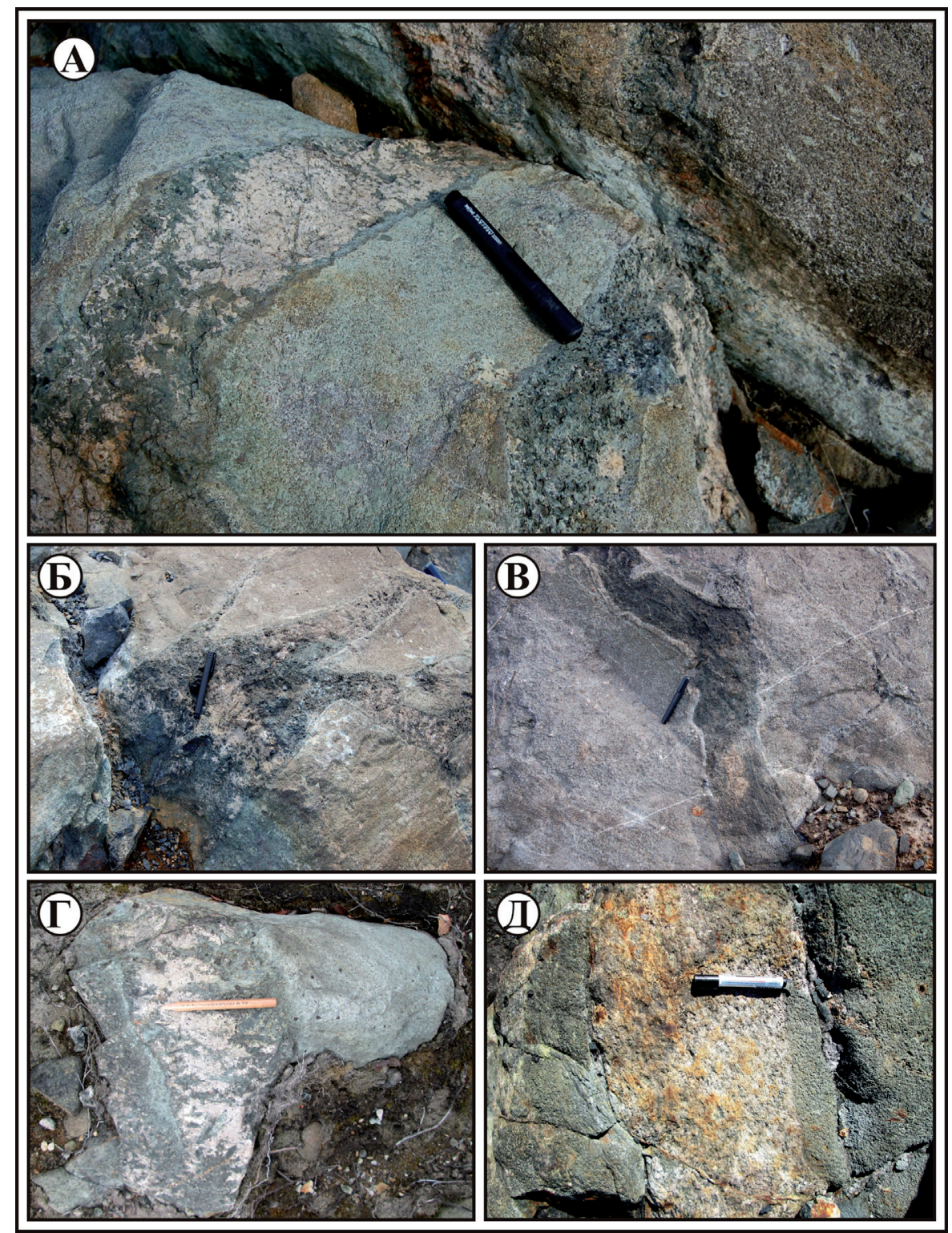

Авторами во время работ 2010-2011 гг. в районе южного приконтактового участка (так называемый «Южносопчинский массив») были детально исследованы жильные тела зоны сочленения Мончеплутона и Мончетундровской интрузии. Тогда по итогам работ было отмечено, что минеральный состав жил изменяется от преимущественно ортопироксенового до амфибол-плагиоклазового (рис. 1). Повсеместно для всех типов жил отмечается присутствие магнетитовой вкрапленности. Наиболее мощные жилы сложены черной на сколе крупнозернистой массивной породой, где хорошо видны крупные выделения магнетита и мелкая сульфидная вкрапленность. Содержание магнетита и сульфидов варьирует от единичных зерен до 3 \% объема породы. Исследования также показали, что с жилами магнетит-плагиоклаз-пироксенового состава, залегающими в метапироксенитах, связана сульфидная и платинометальная минерализация [7, 8]. Важно подчеркнуть, что на схематической геологической карте массива Нюд-Поаз, выполненной в МГРЭ в 1972 г. (ответственный исполнитель отчета В.В. Шолохнев) в пределах Южносопчинского массива были показаны пироксенитовые жилы. Однако в дальнейшем платинометальное оруденение было, на наш взгляд, ошибочно отнесено к рифовому типу, приуроченному к зоне переслаивания пироксенитов и норитов $[1,3]$. Кроме того, было отмечено, что в зоне сочленения Мончеплутона и Мончетундровской интрузии развита магматическая (интрузивная) брекчия, а связанное с жилами сульфидное и ЭПГ оруденение, вероятно, относится не к рифовому, а контактному типу, переотложенному при постмагматических процессах [10]. 
Таким образом, в пределах Мончегорского комплекса (Мончеплутон+Мончетундровская интрузия), достаточно широко развиты тела дайкового и жильного комплексов. Более того, Мончегорский комплекс традиционно считался одним из примеров месторождений богатого сульфидного $\mathrm{Cu}-\mathrm{Ni}$ оруденения жильного типа, к настоящему времени полностью отработанных. Начиная с 80-90-х годов XX в., в пределах Мончегорского комплекса был детально охарактеризован малосульфидный рифовый тип платинометального оруденения, связанный с расслоенными горизонтами. Этот тип оруденения считался наиболее промышленно перспективным в рамках современного этапа освоения Мончегорского комплекса. Однако, исследования последних лет показали также, что сохраняется перспектива разработки и богатых жил с медно-платинометальной минерализацией [5], а также так называемого контактного оруденения [9]. Как раз такой, а не рифовый тип оруденения, может быть представлен в зоне сочленения Мончеплутона и Мончетундровской интрузии, в которой интенсивно развиты процессы брекчирования, дайко- и жилообразования. С определенным типом жил, весьма вероятно, может быть связана и платиометальная минерализация $[7,8,10]$. Однако, жильные образования и их минерализация в зоне сочленения до сих пор изучены весьма неравномерно и в целом пока недостаточно. Этот факт, безусловно, требует продолжения более детальных геолого-минералогических и геохимических исследований, а также проведения (или переоценки) технолого-экономических расчетов.

\section{Литература}

1. Войтехович В.С. и др. Информационный отчет о результатах поисковых работ на металлы платиновой группы в Мончегорском районе (Мончегорский и Мончетундровский массивы) в 1999-2002 гг. Мончегорск. ОАО «ЦКЭ». 2002. Кн. 1. 236 с.

2. Геология и рудные месторождения Мончегорского плутона. Тр. ЛАГЕД АН СССР. Вып. 3. Л.: изд-во AH CCCP. 1956. $328 \mathrm{c}$.

3. Гроховская Т.Л., Иванченко В.Н., Каримова О.В., Грибоедова И.Г., Самошникова Л.А. Геологическое строение, минералогия и генезис ЭПГ-минерализации массива Южная Сопча, Мончегорский комплекс, Россия // Геология рудных месторождений. 2012. Т. 54. № 5. С. 416-440.

4. Докучаева В.С. Геология и петрография придонной части массива Ниттис-Кумужья-Травяная. Окончательный научный отчет. 1960. Апатиты, Фонды КНЦ РАН. 484 с.

5. Казанов О.В., Корнеев С.И., Петров С.В., Фролова А.А. Особенности распределения минералов благородных металлов в медно-платиновых жилах участка Западный Ниттис Мончегорского расслоенного плутона (Кольский п-ов) // Матер. Всерос. конф. с международным участием «Проблемы геологии и эксплуатации месторождений платиновых металлов (I научные чтения памяти проф. В.Г. Лазаренкова)», 25 мая 2016 г., Санкт- Петербург, Горный университет - СПб: Изд-во СПГУ. 2016. С 62-66.

6. Расслоенные интрузии Мончегорского рудного района: петрология, оруденение, изотопия, глубинное строение / Под ред. Ф.П. Митрофанова, В.Ф. Смолькина. Ч. 1. Апатиты: Изд-во КНЦ РАН. 2004. 177 с.

7. Рундквист Т.В., Припачкин П.В., Гребнев Р.А. Особенности взаимоотношений интрузивных тел в зоне контакта ультрамафит-мафитовых комплексов Мончегорский и Главного хребта (участок «Южносопчинский», Кольский полуостров) // Литосфера. 2012. № 3. С 65-79.

8. Рундквист Т.В., Припачкин П.В., Гребнев Р.А., Севостьянов А.Ю., Мирошникова Я.А. Геологическое строение и особенности локализации платинометального оруденения в восточной части Южносопчинского мафит-ультрамафитового массива (Кольский полуостров) // Руды и металлы. 2011. № 5. С 58-68.

9. Karykowski B.T., Maier W.D., Groshev N.Yu., Pripachkin P.V., McDonald I., Barnes S.-J., Savard D. Critical controls on the formation of contact-style PGE-Ni-Cu mineralisation: Evidence from the Paleoproterozoic Monchegorsk Complex, NW Russia / Conference Proceedings (PDFs of abstracts and oral and poster presentations) from SEG 2017: Ore Deposits of Asia: China and Beyond held in Beijing, China. https://www. segweb.org/SEG/_Events/Conference_Archives/2017/Conference_Proceedings/files/pdf/Oral-Presentations/ Abstracts/Karykowski.pdf

10. Pripachkin P.V, Rundkvist T.V., Miroshnikova Ya.A., Chernyavsky A.V. and Borisenko E.S. Geological structure and ore mineralization of the South Sopchinsky and Gabbro-10 massifs and the Moroshkovoe Lake target, Monchegorsk area, Kola Peninsula, Russia. Mineralium Deposita. 2016. V. 51. N. 8. P. 973-992. 